\begin{tabular}{|cc|c|}
\hline ISSN (Online): 2367-6957 & ISSN (Print): 2367-6361 \\
Izvestiya Journal of Varna University of Economics 3 (2020) \\
J Z V E S T I Y A
\end{tabular}

\title{
REASONS TO RETURN DURING GLOBAL PANDEMIC: THE BULGARIAN CASE
}

\begin{tabular}{|c|c|}
\hline & Aleksandar STOYCHEV ${ }^{1}$ \\
\hline \multicolumn{2}{|c|}{$\begin{array}{l}{ }^{1} \text { Department of International Economic Relations, University of Economics, Varna, Bulgaria. } \\
\text { E-mail: aleksandar-stoychev@ue-varna.bg }\end{array}$} \\
\hline JEL: F220 & Abstract \\
\hline $\begin{array}{l}\text { Key words: } \\
\text { Remigration, Return } \\
\text { migration, Reverse } \\
\text { migration, Bulgarian }\end{array}$ & $\begin{array}{l}\text { The aim of this paper is to examine which factors indicate a greater } \\
\text { influence over Bulgarians regarding their decision to return home due } \\
\text { to the COVID-19Pandemic. For this purpose an online survey among } \\
\text { Bulgarians abroad examines their expectations towards the economic } \\
\text { consequences in their country of residence and how it will affect their } \\
\text { attitude regarding possible remigration. } \\
\text { As the main question is not whether, but when the economic crisis } \\
\text { will happen, many emigrants decided to return to their home } \\
\text { countries. This strongly affected the international labour migration. } \\
\text { The biggest factors prompting emigrants to leave could be divided } \\
\text { into two main groups - social, based on emotions and willingness to } \\
\text { be close to their families, and economic, related to employment and } \\
\text { income changes. There is a lack of studies on the examined problem - } \\
\text { how crises are affecting the remigration processes, which is author's } \\
\text { contribution to the researched problem. }\end{array}$ \\
\hline
\end{tabular}
migrants, COVID-19, Global Pandemic.

(C) 2020 University of Economics - Varna

Citation: STOYCHEV, A. (2020). Reasons to Return During Global Pandemic: The Bulgarian Case. Izvestiya Journal of Varna University of Economics, 64 (3), p. 341 - 351.

DOI: 10.36997/IJUEV2020.64.3.341

\section{Introduction}

One of the main driving forces of globalization is the international labour migration (Salimano, 2010). Influenced by various social, political and economic 
changes in the past decades, the globalization processes are increasing human mobility in a global aspect. A problem nowadays that affects international labour migration is the Global pandemic caused by COVID-19 which took over in March 2020.

Since its outbreak in March 2020, the COVID-19 Pandemic faced the world with many challenges. Governments across the globe conducted restrictions as a protective measure against the spread of the infection. Guided by the instructions of the World Health Organization, they were similar in almost every country. Some of them were the closure of international borders, travel bans, suspension on free mobility of people and services (WHO, 2020).

This paper studies one of the aspects of international migration experiencing big movement during the crisis - the remigration, referred to also as reverse migration and re-emigration.

\section{Literature review}

Remigration is the act of returning back to the home country from a migrant after a significant period of time (Dustmannet al, 2007). According to the United Nations Statistics Division for collecting data on international migration, returnees are „persons returning to their country of citizenship after having been international migrants (whether short-term or long-term) and who are intending to stay in their own country for at least a year" (OECD, 2008).

The motives to return back to the country of origin could be several, depending on the individuals' reasons. The theories put them in a few groups. The International Organization for Migration (IOM) group them as voluntary, forced, assisted and spontaneous migration (IOM, 2019).

According to the neoclassical theory, the motives for returning to the country of origin are two - economic and social (Constant et al, 2003). Failed attempt to settle permanently in the host-country and meeting the financial expectations of the emigrant are considered in the first group. When looking at the sociological motives, the economic aspects are not considered that significant. In this group, the individuals are affected more by decisions related to their ethnic origin - relatives and families. Neo-classicists consider that if they prevail over the economic ones, the possibility of return is much higher. External factors such as economic changes, political changes, war and other crises are also taken into consideration in this theory.

On the other hand, the New Economics of Labour Migration (NELM) take return migration not as a failure of settlement, but as a successful achievement of the household goal based on an individual migrant risk strategy (Cassorino, 2004; Constant and Massey, 2002; Stark, 1991). Unlike the Neo-classicist, NELM focus not 
A. Stoychev.

Reasons to Return During Global Pandemic: The Bulgarian Case

as much on the economic consequences, but on the social impact of the household which extends the context of the analysis (King and Christou, 2008). Some theories even deny return as part of the migration process. They consider it either as a failure or success of migration (Cassarino, 2004). On the other hand, a study from 2019 puts motives for remigration in twelve reasons for individuals to leave (Stark, 2019). The list contains economic and social motives ${ }^{1}$. Stark comes to the conclusion that the motives are more complex than simply putting them in success or failure.

Many other studies on the topic examined the diasporic migrants (Tsuda, 2009a). They state that even if the economic motives are primary for the return, ethnic ties and emotional reasons are also important. The relative importance of economic and social motives is different in every ethnic group (King et al., 2011).

Push and Pull factors are also being considered and emphasized as motives for remigration (Gmelch, 1980). In some cases, the decision to return is influenced by the negative Push (repulsive) factors in the host country. Lack of work and lower incomes can be mentioned as such. At the same time, Pull (attracting) factors from the sending country may also have impact on individuals' motives to leave - for example, proximity to the family (Makni, 2010).

\section{The Bulgarian case}

According to data from 2019, 1.3 million Bulgarians live abroad (Angelov, 2019).The net migration rate in Bulgaria for 2019 is -5.03 per cent (-2 012 people) according to the National statistical institute of Bulgaria. These numbers show and confirm the long-term trend in the international migration in Bulgaria, which has been increasing over the past few decades. However, as of the current problem, we can assume that the Pandemic might be a driving force for remigration to become more intense. An Open Society Institute - Sofia report from 2010 includes a study of the migration processes in Bulgaria during and after the 2008 economic crisis. The study shows that despite the severe economic consequences during that period, Bulgarians who decide to stay abroad long-term are very unlikely to return because of the crisis. (Krasteva et al, 2010)

However, the current crisis with the COVID-19 pandemic is different. Even though the economic downturn might be the same, or even worse, the reasons to remigrate would be different.

\section{Research methodology}

An online survey was conducted at the beginning of April 2020. The questionnaire consists of open-ended and closed-ended questions and was conducted 
on social media among 28 Bulgarian emigrant groups. After reaching the target of 600 respondents, the collection of answers was suspended.

The respondents are Bulgarian citizens living in 23 countries on 5 continents Europe, North America, Africa, Asia and South America. The most answers were received from the Netherlands (21.6\%), Spain (16.3\%), Denmark (15\%) and the USA $(8.5 \%)$ (Fig. 1 ) which covers nearly $60 \%$ of all respondents.

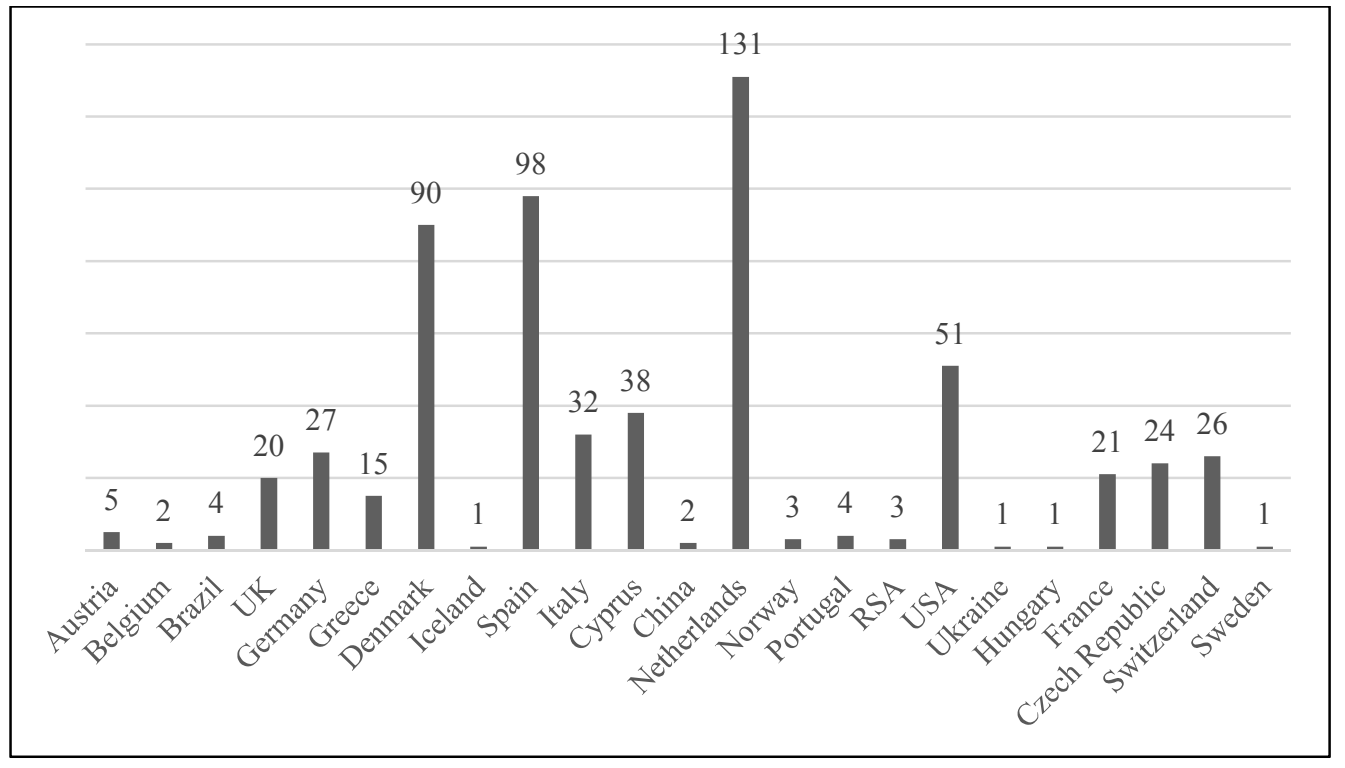

Fig. 1. Respondents by country of residence

Source: Author's survey.

The survey aims to examine the observations of Bulgarian migrants regarding the COVID-19 pandemic and how the current situation affects their motives for returning to Bulgaria. Two main groups of factors are considered - social and economic. The first group includes heath concerns and willingness to be close to the family. The second group - employment and income change.

In this line of thinking, the first hypothesis suggests that during a global pandemic and an impending economic crisis, emigrants are much more likely to return to their home countries. Especially when some of the main factors for them to migrate in the first place are being affected. The second hypothesis suggests that the economic motives would be in prevail for remigration over the sociological ones like 
A. Stoychev.

Reasons to Return During Global Pandemic: The Bulgarian Case

health concerns and being close to the family. The third hypothesis suggests that factors as employment status and length of stay abroad are the most important when making the decision to return. The statistical software SPSS has been used for data processing as $\chi^{2}$ test has been applied to analyse the results.

\section{Analysis and interpretation of the results}

The sample involved 443 women (73.8\%) and 157 males (26.2\%). Of all 600 respondents, $49.2 \%$ have secondary education, $45.2 \%$ have university degree, $4 \%$ primary education and $1.7 \%$ - $\mathrm{PhD}$. The respondents are a diverse sample, both in terms of age and occupation. All participants are over the age of 18; most are from the $40-49$ age group (36.5\%), $49.8 \%$ of respondents are employed full-time and $20 \%$ are unemployed.Table1shows the structure of respondents by individual demographic characteristics - sex, age, education.

Table 1

Socio-demographic characteristics of respondents in Bulgaria

\begin{tabular}{|c|c|}
\hline Characteristics & All \\
\hline Sex & $26 \%$ \\
\hline Male & $73 \%$ \\
\hline Age & \\
\hline $18-29$ & $11.2 \%$ \\
\hline $30-39$ & $25.2 \%$ \\
\hline $40-49$ & $36.5 \%$ \\
\hline $50-59$ & $21.3 \%$ \\
\hline $60+$ & $5.8 \%$ \\
\hline & \\
\hline Education & $4 \%$ \\
\hline Primary & $49.2 \%$ \\
\hline University & 45.25 \\
\hline PhD & $1.7 \%$ \\
\hline Length of stay abroad & \\
\hline Less than an year & $7.5 \%$ \\
\hline $1-3$ years & $9.7 \%$ \\
\hline $3-5$ years & $12.8 \%$ \\
\hline More than 5 years & $70 \%$ \\
\hline
\end{tabular}

Source: Author's survey. 
The motives for migration are listed in seven groups including social and economic reasons for leaving the country in first place. The respondents had the opportunity to choose more than one answer, according to their personal motive to migrate. As seen from the figure below, it can be easily concluded that most accurate are the "Pull" factors such as better standard of living, higher income and family reasons.

In a 2018 study, examining the attitudes towards labor migration of Bulgarians, it was found that better income is the most important motive for leaving the country. (Alexandrova, 2019).On the other hand, a survey obtained in 2011 among Bulgarian students, shows that income is not the main reason for young people to leave the country. For them, the biggest incentive is employment (Makni, 2011).

Therefore, from the obtained data the following conclusion can be made: Bulgarian motives to migrate are strongly influenced by the idea to achieve better economic benefits abroad. With this knowledge it can be assumed that one of the main reasons to return would be if any of these indicators got worse.

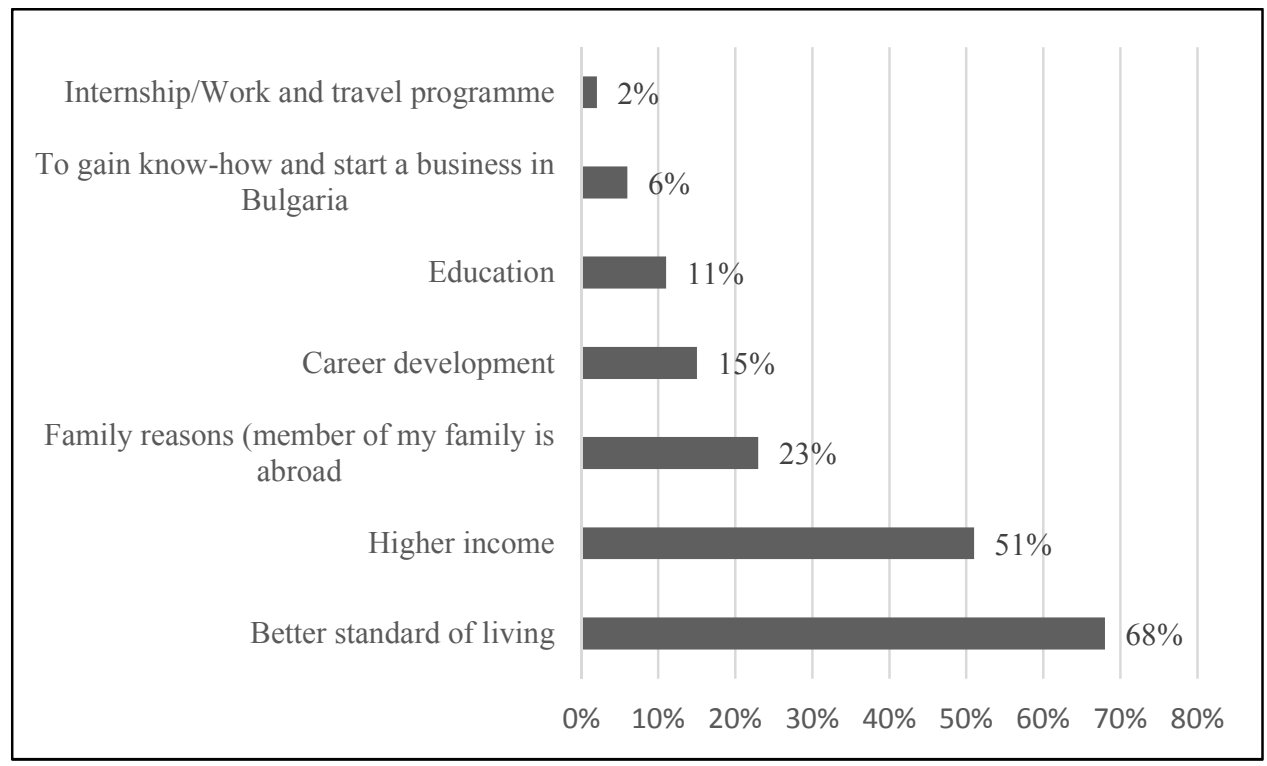

Fig. 2. Migration motives

Source: Author's survey.

Hypothesis 1suggested that during the Pandemic, most of the migrants would plan or already returned home. Considering the total number of respondents in the 
A. Stoychev.

Reasons to Return During Global Pandemic: The Bulgarian Case

study, $49.5 \%$ indicated that they remain firmly abroad, regardless of the circumstances, $34.5 \%$ said they would return in a short period of time, $15 \%$ were likely to return for the long term, and $1 \%$ have already returned to Bulgaria. Therefore, half of the respondents (50.5\%) are somewhat hesitant and will return, whether for a short or long period (Table 2). That partly confirms the statement that many Bulgarian emigrants will return to Bulgaria because of the pandemic.

It is noteworthy that we could divide the correspondents into two groups - those who are firmly staying abroad and the other half which will remigrate sooner or later.

Through the $\chi^{2}$ analysis we test Hypothesis 2 . For this purpose we study the presence of a statistically significant difference between the two groups in terms of social and economic reasons defining their decision to return or stay abroad. The test lead to the solution: adoption or rejection of the null hypothesis which states that economic factors have bigger influence.

Table 2

\section{Reasons to remigration and willingness to return}

\begin{tabular}{|c|c|c|c|c|}
\hline \multicolumn{2}{|c|}{} & \multicolumn{2}{|c|}{ Willingness to return } & \multirow{2}{*}{ Total: } \\
\cline { 3 - 5 } & Staying abroad & $\begin{array}{c}\text { Planning or already } \\
\text { returned }\end{array}$ & \\
\hline \multirow{2}{*}{$\begin{array}{c}\text { Reasons to } \\
\text { return }\end{array}$} & $\begin{array}{c}\text { Sociological } \\
\text { (Family reasons etc.) }\end{array}$ & 70 & 112 & $182(30 \%)$ \\
\cline { 2 - 5 } & $\begin{array}{c}\text { Economic } \\
\text { (Income change etc, })\end{array}$ & 227 & 191 & $418(70 \%)$ \\
\hline \multicolumn{2}{|c|}{ Total: } & $297(49.5 \%)$ & $303(50.5 \%)$ & 600 \\
\hline
\end{tabular}

Source: Author's survey.

The test shows significant correlation (Chi-Square $\mathrm{p}<0.01)$ and weak connection (Cramer's $\mathrm{V}=0.146$ at $\mathrm{p}<0.01$ ). The factor having bigger influence on migrants to return are the economic ones $-63 \%$ of those planning to or already returned, made their decision influenced by economic reasons (Table 2). By economic we consider income change, employment status, and by social- family reasons and global pandemic or a crisis. On the other hand, overall $70 \%$ of the migrants put economic factors as most influential when it comes to plan their stay or leave. This confirms that the economic motives are prevalent in terms of making a decision for remigration.

Concerning the period of time spent abroad, the European commission defines three groups of migrants - long-term (permanent), short-term and temporary migrants (European commission). International migration can be classified also as short-term 
(seasonal), medium-term and long-term (Marinov, 2007). A vast majority of the respondents in the survey are long-term migrants $-70 \%$ (longer than 5 years), followed by Bulgarians who are abroad for a period of 1-5 years (23\%) and least are those for less than one year $(7 \%)$.

Using the same $\chi^{2}$ analysis we test hypothesis 3 which suggests that employment and length of stay abroad have biggest influence over the decision about remigration. It turns out that only the length of stay is an essential factor (Chi-Square Pearson $\mathrm{p}<0.01$ ) and the correlation is weak (Cramer's $\mathrm{V}=0.152$ at $\mathrm{p}<0.01$ ). The employment shows insignificant connection (Chi-Square Pearson $\mathrm{p}>0.01$ ). From the test, the null hypothesis is being rejected and the alternative is adopted. This suggests that from those indicators only the length of time abroad can be taken as statistically significant when it comes to make a decision to return during the pandemic.

The respondents were asked if they felt their workplaces endangered and what the crisis impact on their income was. The results were implemented by the 5-point Likert scale where 3 is neutral, answers over 3 suggest agreement that the crisis is having a negative impact on their income or workplace safety. While answers below three rather suggest disagreement. One third of the respondents don't feel their workplace endangered and 23\% are strongly concerned of being left unemployed. The same trend can be found regarding income. $35 \%$ of the migrants haven't seen any change in their disposable income and $23 \%$ already feel negative consequences of the economic crisis. From those who already experience decrease, $68 \%$ state that might return for a long or short term. The rest $42 \%$ are firmly staying abroad even though more than one third of them are unemployed. Long-term migrants are supposed to have better settlement in their current country of residence and have built stable social connections throughout their stay, compared to those who are abroad for a shorter period. Short-term migrants are still insecure and unsettled.This partially confirms that unemployment is an essential factor for remigration.

Table 3

\section{Observations regarding workplace safety and income change}

\begin{tabular}{|l|l|l|l|}
\hline \multicolumn{2}{|c|}{ Workplace endangerment } & \multicolumn{2}{c|}{ Income change } \\
\hline Strongly No & $208(35 \%)$ & Strongly No & $180(30 \%)$ \\
\hline Rather not & $90(15 \%)$ & Rather not & $103(17 \%)$ \\
\hline Neutral & $130(22 \%)$ & Neutral & $114(19 \%)$ \\
\hline Rather yes & $37(6 \%)$ & Rather yes & $52(9 \%)$ \\
\hline Strongly Yes & $135(23 \%)$ & Strongly Yes & $151(25 \%)$ \\
\hline
\end{tabular}

Source: Author's survey. 
A. Stoychev.

Reasons to Return During Global Pandemic: The Bulgarian Case

It's noteworthy that Bulgarians who live abroad for a period of time less than one year are more likely to return. Only $24 \%$ of them are firmly staying abroad and the rest $75 \%$ will return or already have. Also, migrants who are in the same group feel a greater negative impact on their income (31\%) compared to those being abroad for a long time $(24 \%)$. It is the same with securing the workplace. Despite that, a conclusion can be made that most of the Bulgarian migrants in the study are not experiencing negative consequences amid the pandemic.

An interesting paradox is being observed. One fifth of all the respondents are unemployed (20.5\%). However, $40 \%$ of them are definitely staying abroad, as the rest are planning to or already returned. It's noteworthy that when asked why most Bulgarians return home during the Pandemic, they state that being left without a job because of the crisis is the number one factor. Then there comes the following question - why, if they consider that as the most important reason, they are decisively not returning despite of their employment status? It can be assumed that the sample is not representative and probably the unemployed migrants benefit from the social policies in their current country of residence. Here as well one can consider the fact that most of the respondents are in countries such as Denmark, the Netherlands and Spain, where the governments have stronger support for the unemployed than in Bulgaria. Confirming that are some of the open-answers given by respondents, stating that most of the Bulgarians remigrating during the crisis are from the minority ethnic groups, who are probably not in the researched social media diaspora.

The results from the study clearly indicate that economic factors and motives are the main drivers of the remigration processes during the COVID-19 pandemic among Bulgarian migrants. Social factors, such as health concerns and willingness to be close to their families are left behind.

\section{Conclusion}

A conclusion could be drawn that most of the Bulgarian migrants are still not affected by the COVID-19 pandemic in way of changing their current place of living and economic well-being. Although half of the respondents are decisively staying abroad, the other half are planning to or have already returned to Bulgaria. These results partially support the first hypothesis that migrants are more likely to remigrate during a pandemic.

Most significant for the remigration processes are the economic factors. Social factors such as health concern and panic, as a result of the pandemic, have a minimal effect on the remigration decisions, which confirms hypothesis number two.

Length of stay is also a factor influencing individuals' decisions to return. This can be assumed as a result of long-term settlement of Bulgarians in their current place 
of residence. It turns out that, opposite to the author's expectations, employment is not a significant factor for making the decision to return. Likewise, most of the migrants who feel a negative impact on their disposal income are planning to or have already returned. Migrants feeling most vulnerable regarding disposal income and their workplace are those living abroad for a period of time less than a year. The chance for them to return is bigger.

Despite the great number of unemployed migrants staying abroad, Bulgarians consider loosing one's job as the biggest reason for individuals to return. This gives reason to assume that the social policy in the countries of origin is supporting the unemployed better than the Bulgarian government, which makes migrants to stay abroad. On the other hand, a large part of the migrants who have already returned are not covered by the study.

\section{End Notes}

${ }^{1}$ Purchasing power; Strategic accumulation of human capital; Occupational status and social prestige; Asymmetric information; Social comparisons: ordinal preferences; Relative deprivation: cardinal preferences; Matching in the marriage market, and divorce; Receipt of inheritance; Meeting a target; Shocks at home; Costly separation caused by migration; Failure.

\section{References}

1. Alexandrova, N.,(2019) Individual Attitudes towards Labour Emigration in Bulgaria (a descriptive analysis). Economics and Computer Science, 5(3), pp. 27-44.

2. Angelov, G. (2019) Kadeikolkosabulgarite v chuzhbina, Open Society Institute - Sofia [Online] Available at https://osis.bg/?p=3053 [Accessed on: 06/06/2020].

3. Constant, A., Massey, D. (2002) Return migration by German Guestworkers: Neoclassical versus New Economic Theories. 631-653.

4. Dustmann, C., Weiss, Y. (2007) Return Migration: Theory and Empirical Evidence from the UK, 236-256

5. Gmelch, G., (1980) Return migration. Department of Anthropology, State University of New York [Online] Available from: https://www. annualreviews. org/doi/pdf/10.1146/annurev.an.09.100180.001031 [Accessed 18/04/ 2020].

6. Krasteva, A., Angelov, G., Ivanova, D., (2010)Tendencii v transgranichnatamigraciyanarabotnasilaisvobodnodvizheniena hora - efektiza Bulgaria.

7. Kunuroglu, F., van de Vijver, F., \&Yagmur, K. (2016). Return Migration. Online Readings in Psychology and Culture, 8(2). [Online] Available at: https://doi.org/10.9707/2307-0919.1143 [Accessed on: 06/06/2020]. 
A. Stoychev.

Reasons to Return During Global Pandemic: The Bulgarian Case

8. King, R., Christou, A. (2008) Cultural Geographies of Counter-Diasporic Migration: The Second Generation Returns 'Home, p. 12.

9. Long term migration, European commission [Online] Available at: https://ec.europa.eu/home-affairs/what-we-do/networks/european_migration network/glossary_search/long-term-migration_en [Accessed on 06/06/2020].

10. Marinov, V. (2007) International Labour Migration: Economic Aspects, Nauchnitrudove, University of National and World Economy. 17 [Online] Available at: http://departments.unwe.bg/Uploads/ResearchPapers/Research\%20 Papers_vol2_ 2007_No1_V\%20Marinov.pdf [Accessed on: 06/06/2020].

11. Makni, V. (2010) Intelektualnaemigracia: efekt v dvelitsa. IK Gea - Print Varna, 29-31.

12. Makni, V. (2011) Student migration potentian: The case of Bulgaria, SouthEastern Europe Journal of Economics 2, 187-206.

13. Milcheva, E. (2020) Stotitsihilyadibulgari se pribrahazaradikoronavirusa. Deutsche Welle Bulgaria (DW) [Online] Available from: https://p.dw.com/p/3a3PW [Accessed 20/04/2020].

14. National statistical institute of Bulgaria (2020) International migration by age and sex 2019 [Online] Available at: https://www.nsi.bg/en/content /6697/ international-migration-age-and-sex [Accessed on 06/06/2020].

15. Return migration. Migration data portal [Online] Available from: https://migrationdataportal.org/themes/return-migration[Accessed 18/04/2020].

16. Solimano, A. (2010) International Migration in the Age of Crisis and Globalization: Historical and Recent Experiences. Cambridge University Press. 1-21

17. Stark, O. (2019) Behavioural Public Policy, Volume 3, Issue 1, $104-126$ [Online] Available at: https://www.cambridge.org/core/journals/behavioural-publicpolicy/article/behavior-in-reverse-reasons-for-return-migration/3C82F8AC4DE110 6D3ECD845DB0BC9C11/core-reader[Accessed on: 06/06/2020]

18. United Nations, (1998) Recommendations on Statistics of International Migration, Revision 1, Statistical Papers, Series M, No. 58 [Online]

19. World Health Organization, (2020) Timeline of WHO's response to COVID-19 [Online] Available from: https://www.who.int/news-room/detail/29-062020-covidtimeline[Accessed on: 05/06/2020]

20. Yayboke, E. (2020) Five Ways COVID-19 Is Changing Global Migration. Center for strategic \& international studies (CSIS)[Online] Available from: https://www.csis.org/analysis/five-ways-covid-19-changing-global-migration [Accessed 20/04/2020]. 